Témoigner Témoigner. Entre histoire et mémoire

Getuigen Revue pluridisciplinaire de la Fondation Auschwitz

$124 \mid 2017$

La musique dans les camps

\title{
Presentation. Music in the camps
}

Présentation. La musique dans les camps

\section{Klaas Coulembier}

\section{Q OpenEdition}

\section{Journals}

\section{Electronic version}

URL: https://journals.openedition.org/temoigner/5720

DOI: 10.4000/temoigner.5720

ISSN: 2506-6390

\section{Publisher:}

Éditions du Centre d'études et de documentation Mémoire d'Auschwitz, Éditions Kimé

Printed version

Date of publication: 2 April 2017

Number of pages: $42-49$

ISBN: 978-2-930953-00-7

ISSN: 2031-4183

\section{Electronic reference}

Klaas Coulembier, "Presentation. Music in the camps", Témoigner. Entre histoire et mémoire [Online], 124 | 2017, Online since 30 November 2021, connection on 01 December 2021. URL: http:// journals.openedition.org/temoigner/5720 ; DOI: https://doi.org/10.4000/temoigner.5720 


\section{DOSSIER}

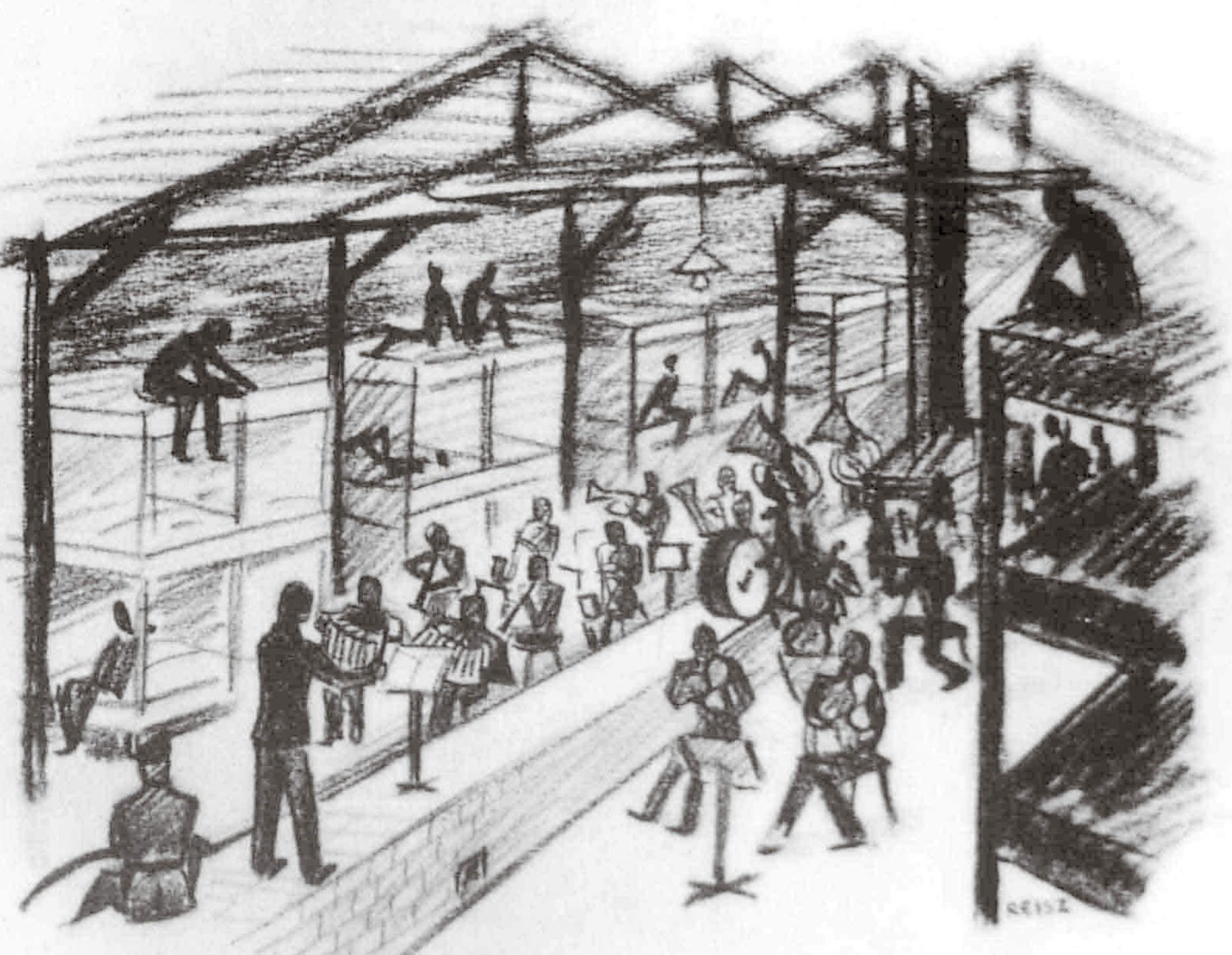


Un enfant dans le noir, saisi par la peur, se rassure en chantonnant. Il marche, sarrête au gréde sa chanson. Perdu, il s'abrite comme il peut, ou s'oriente tant bien que mal avec sa petite chanson. Celle-ciest comme l'esquisse d'un centre stable et calme, stabilisant et calmant, au sein du chaos. (Deleuze \& Guattari 1980, 382)

A child in the dark, gripped with fear, comforts himself by singing under his breath. He walks and halts to his song. Lost, he takes shelter or orients himself with his little song as best he can. The song is like a rough sketch of a calming and stabilizing, calm and stable, center in the heart of chaos. (Deleuze \& Guattari 1987, 311)

far removed from the daily horror of the camps that any occurrence of music in this context is truly significant. Different appearances of music may range from the most intimate, self-comforting humming of the prisoner facing his or her certain death, to the songs used in the extravagant and impudent propaganda installed by the Nazi regime. The former resonates with the above quotation from Deleuze. The most striking example of the latter is the ghetto of Theresienstadt, where many intellectuals and artists were brought togethe and a flourishing cultural life developed as a façade to "reassure" the Red Cross and the world. In between these extremes, music could be used as entertainment, as diversion, as punishment, as torture, as indoctrination, and so on

Music is one of the many threads along which one can recount the story of the Holocaust and the Second World War, and this story draws on a much wider perspective than that of the concentration camps alone. Although the contributions to this dossier share a focus on the presence of music within the boundaries of the camps, it is still interesting to consider the role of music in the Nazi ideology.

\section{Good and \\ bad music}

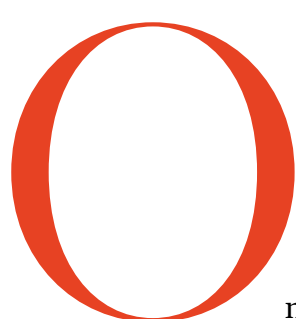
mechanisms in the long and comple process that enabled the cruelties of the Holocaust was the unambiguous distinction between good and bad, and the exclusion of certain population groups. Not only Jews were the victin of this ideology, but also gypsies, people with disabilities or the mentally ill. In the ideal Aryan society, there could only be room for artistic products tha illustrated or even stimulated the pure and elevated culture of the German people. Richard Wagner, who had lived from 1813 to 1883 , was often set as an example, and his anti-Semitic texts (althoug written in a rather different politica climate than that of the 1930s) were eagerly adopted to underscore the long tradition of German cultural supremacy. Compositions or other artistic product considered inappropriate were labelle as "degenerated" (entartet). In 1937 more than 600 artworks were removed from German museums because of their classification as such. Rather than immediately destroying these painting and sculptures, the authorities groupe them in an exhibition entitled Entartete Kunst, which travelled throughout the major cities in Germany and Austri
(Schuster 1988). The exhibition set out to show people how certain artists had chosen the wrong path. In the words of art historian Benjamin Buchloh, " $[\mathrm{t}] \mathrm{he}$ rhetoric of the Nazi exhibition was exhortative and prohibitive; it claimed to have restored the normative criteria according to which artistic production would from now on have to be conceived, produced, and staged" (Buchloh 2014, p. 55).

Not only the visual arts were subjected to this kind of state-censorship Asmaller exhibition on Entartete Musik followed quickly, referring to Jewish composers or composers that developed a more modern, avant-garde style in their work. In the same line of thought, jazz music (rooted in the music of black slaves) and folklore music from Eastern Europe were also non grata, since they were closely tied to particular non-German identities and could thus evoke nationalist feelings against the German supremacy. Many com-

posers, such as Arno

Schoenberg, Kurt Weill, or Erich Korngold emigrated from the country to settle in the United States. Others decide to stay, often with trag results, as in the case of zech composer Pave Haas. He was deported to Theresienstadt in 1941, last stop before Auschwitz, where he ied in the gas chambers in 1944.

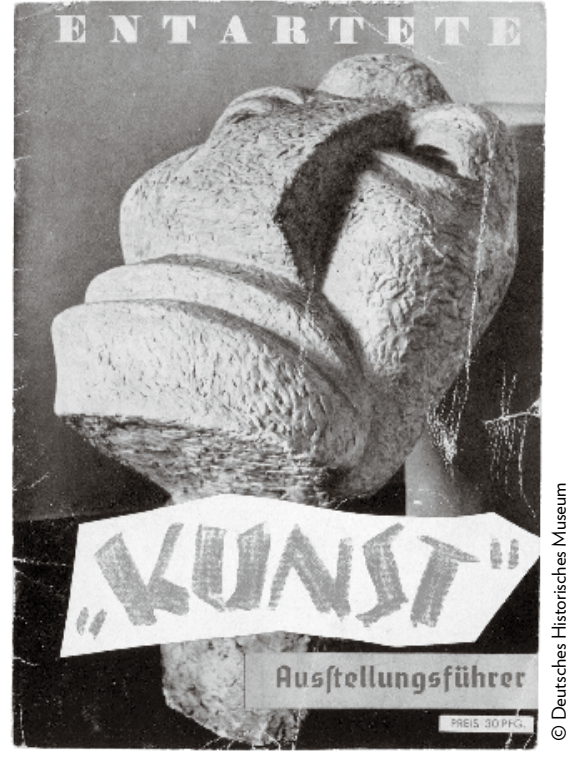


Theresienstadt, a model town in Bohemia

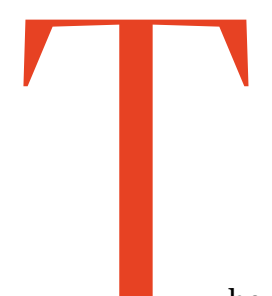

L_ he single most important place for music and culture among the many camps and ghettos in Europ was Theresienstadt, the German name for Terezín. This is one of the place discussed in the essay by Amaury d Closel. In the so-called transit camp. many elderly and intellectual Jews were imprisoned, including a high number o musicians and composers. There are lot of well-known stories from survivor by which we get a glimpse of the double-sided nature of this unique place. Some people may have been unaware of what happened outside, contente to spend their days with music, albeit in severe living conditions. Others did probably know their destiny, but held on to the cultural events in the town as a kind of last hope. For a brief moment Theresienstadt almost became the idylic place the Germans claimed it to be. In response to international criticism and rumours about mass-extinction of Jewish people, the International Re Cross was invited to come and inspect the "model ghetto" of Theresienstad. The town was cleaned, buildings were repainted, the inhabitants were properly dressed, and a performance of the famous and popular opera Brundibar, composed in Theresienstadt by the Jewish Czech composer Hans Krása, displayed the joy and happiness of both musicians and spectators. This counts as one of the most mind-blowing examples of Nazi propaganda, including the deliberate use of music. Afilm was shot for the same purposes, and distributed under the heading Theresienstadt. Ei Dokumentarfilmaus demjüdischenSiedlungsgebiet. The film was also known as Der Führer schenkt den Juden eine Stadt In reality, Theresienstadt was as crue a place as the many other camps or ghettos. Almost 34,000 people died in the ghetto, while another 88,000 were deported to extermination centres, mainly Auschwitz.

Among these deported people was Viktor Ullmann, son of a Jewish-Austrian officer. Ullmann studied with Arnold Schönberg, one of the (Jewish) composers whose music was clearly entartet because of its atonal, modernist language. Together, they had founded the "Verein für Musikalische Privatauftuhrungen", an organisation that enabled and promoted performances of modern compositions in the early 1920s. At the moment of the National Socialist seizure of power in Germany, Ullmann lived in Stuttgart, which he immediately left for Prague On 8 September 1942, he was deported to Terezin, where his musical talent wa recognized. He played an important role in the musical life there, but on 16 October 1944 he was put on a liquidation transport to Auschwitz. He would die in the gas chamber two days later. Due to this untimely death, he would neve witness the premiere of his opera $D e$ Kaiser von Atlantis. The opera would even remain unperformed until 1975 . A number of his other compositions from
Terezín survived, one of which is the centrepiece on the latest disc of Hélio Azoulay and the Ensemble de Musique Incidentale. Before being transferre to Auschwitz, Ullmann was workin on another opera telling the story of Jeanne d'Arc. The entire libretto has been preserved (and is included in this issue, together with the album), but only two pages of the music remain. Hélio Azouly and the musicians took this fragment as a point of departure for a new musical adventure. The interview by Daniel Weyssow of the Auschwitz Foundation shows that even today, creative sparks originate from these historical events.

\section{Music in the death camps}

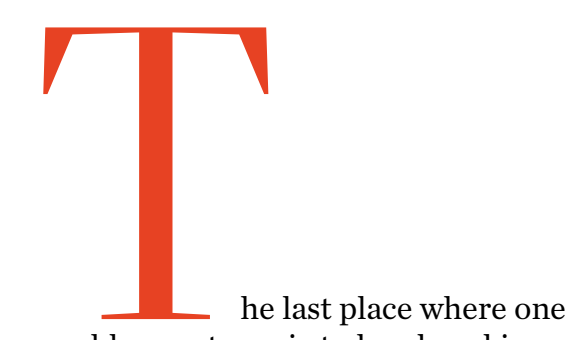
would expect music to be played is an extermination centre. In his contribution to this dossier, Bruno Giner zooms in on the practices in the camps of Aktion Reinhardt, the straightforward campaign of the Nazi regime to "solve" the Jewish question. He pictures the early examples of musical propaganda and gives some more details on the specific situations in Bełżec, Sobibór en Treblinka. The schizophrenic way of life - including both wedding ceremonies and massacres in the same camps is exemplified by the inclusion of a number of typical camp songs. These lyrics must have sounded time and again within the barbed wire fences, sung by inmates young and old. In conclusion, Giner wonders if the abuse of music in this environment should make us hate music. If music can serve purposes far beyond human dignity, can we still cherish it as one of the highest art forms?

In his study on music in the concentration camps between 1933 and 1945 Guido Fackler investigates how music was a part of daily life for the inmates at places such as Dachau, Auschwitz, Mauthausen and many others. His research 
is based on archive studies (including memoirs and a large body of secondary literature) and - importantly - interviews with survivors. Fackler makes distinction between music that was performed or created by order of the SS, an music that arose from the initiative of the prisoners. The first category covers number of routine situations: collective singing while marching from one place to another, singing humiliating song during executions, or during labour But music also sounded from loudspeakers, initially in order to re-educate the inmates. In combination with new broadcasts on Hitler's successes, the German military march music that was played must have had an enormous demoralizing effect.

In addition to disciplinary use of music, Fackler points at the performances inmates had to give during private or official parties or gathering of SS officers. In such a context, popular music that would have been calle entartet by the official regime was performed as well, and according to Fackler SS members would occasionally eve join the prisoners and play along. If anything, this shows that within the bound aries of the camps, miniature societie developed in which the hierarchies an rules could sometimes deviate from the broader Nazi policy.

Perhaps the most remarkab aspect of music life in the camps is the existence of so many organized music ensembles, ranging from small group of two or three people to large symphonic orchestras and choirs. Fackle provides ageneral overview of the mo important aspects of this peculiar phenomenon, which is further explored an elaborated in the contribution to this dossier by Amaury du Close

\section{Identity}

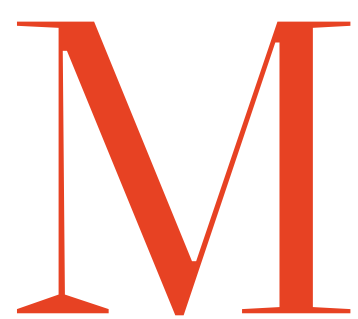
camps had systems where certain prisoners were given authority over others, resulting in a very restricted form of self-government. In this respect, musical performances could also arise from spontaneous initiatives, providing consolation or reminding the inmates of their previous lives. In a world where each kind of identity is taken away by shaving people's heads and tattooing a number on their naked bodies, music - and especially music with a strong folkloristic character - can be a powerful tool to establish a feeling of being connected, the sense of being part of a community. This notion of identity is a central topic in Minako Waseda's essay on the role of music in the Japanese-American camps that were installed after the Japanese attack on Pearl Harbor. More than 120,000 people of Japanese ancestry, many of them born in America, were deprived of everything and sent to improvised camps in remote areas. Unlike the German camps, these camps were not designed to exterminate the Japanese population in the United States. Thei main purpose was to remove anyone with Japanese blood from society to prevent anti-American riots in case of a Japanese invasion. The official policy of the War Relocation Authority was to "Americanize" them. Minako Wased describes how life in these camps wa in a certain way culturally rich, because of the high concentration of masters in traditional Japanese arts and the abundance of leisure time provided by the authorities to maintain relative peace and quiet in the camps. This particular episode of American history has lon remained underexposed, until the documentary film Hidden Legacy (2014) revealed it in all its complexity and (re) shaped collective memory.
This dossier thus shows how music was an important aspect of life in the camps and ghettos of the 1930s and (940s, both in Europe and in the USA. Music was used for propaganda, for entertainment, for military purposes, and sometimes for consolation. Music was a means of feeling connected with fellow prisoners, and a reminiscence of a lost identity. In some cases, music was a life-saver. In the 2013 documentary film The Lady in Number 6: Music Saved My Life, cellist and Holocaust survivor Anita Lasker-Wallfish recalls the advice of her father: "Put as much as you can into your head, because that is something nobody can take away from you."

A child in the dark, gripped with fear, comforts himself by singing under his breath. He walks and halts to his song. Lost, he takes shelter or orients himself with his little song as best he can. The song is like a rough sketch of a calming and stabilizing, calm and stable, center in the heart of chaos.

WORKS CITED

- Buchloh, Benjamin, 'The Dialectics of Design and Destruction: The Degenerate Art Exhibition (1937) and the
Exhibition internationale du Surréalisme (1938)', October 150, 2015, 49-62. - Deleuze Gilles \& Fálix G

- --., A Thousand Plateaus, translated from the French by Brian Masumi, London: Continuum, 1987. - Schuster, Peter-Klaus (ed.), Nationalsozialismus und 'Entartete Kunst'. Die 'Kunststadt' München 1937, München
Prestel-Verlag, 1988. 